\title{
Fungsi-fungsi nilai budaya lokal pada organisasi publik
}

\author{
Functions of local culture for public organization
}

\author{
Syamsir Torang \\ Kopertis Wilayah IX Sulawesi, Universitas Indonesia Timur \\ PASCASARJANA Universitas Indonesia Timur, Jalan Rappocini Raya No 171 Makassar, \\ Indonesia \\ Telephone: +62 411 - 831555 \\ E-mail: syamsirtorang@ymail.com
}

\begin{abstract}
Public organization is the government instrument which has role system, flow activities, and pattern of team work relation; it involves civil servants to serve the public. The objective of this study is to analysis the functions of local culture in the Centre General Hospital of Wahidin Sudirohusodo Makassar as public organization. This study is a qualitative research which applies as a case study approach. The data sources are primer and secondary data. The primer data was collected through observation of social situation (place, actor, and activity) and structured interview of the informants. The secondary data was collected through documentations. The technique of data analysis was performed through data collection, data reduction, data display and conclusion. The indicators of the study are functions (social identity, social cohesion, sense-making and control mechanism, motivation source, and inspiration source) of the local culture value (sipakatau). Sipakatau is the Bugenese language that means to appreciate and respect each other. This value has been espoused by Bugenese and Makassarise in applying their activities. The result of the study indicates that local culture value (sipakatau) has been functioned as social identity, social cohesion, sense-making and control mechanism, motivation source, and inspiration source by the Centre General Hospital of Wahidin Sudirohusodo Makassar.
\end{abstract}

Keywords: sipakatau, local value, public organization, respect to others, social identity

\begin{abstract}
Abstrak
Organisasi publik merupakan instrumen pemerintah yang memiliki sistem, alur, serta pola hubungan dalam kerja tim yang melibatkan pewgawai negeri sipil untuk melayani negara. Tujuan dari penelitian ini adalah untuk menganalisa fungsi budaya lokal dalam organisasi publik, yakni rumah sakit Wahidin Sudirohusado, Makasar. Penelitian ini merupakan studi kualitatif dengan pendekatan studi kasus. Sumber data didapatkan secara primer dan sekunder. Data primer dikumpulkan melalui observasi dari situasi sosial (tempat, aktor, dan aktivitas) dan wawancara terstruktur dengan informan. Data sekunder dikumpulkan melalui dokumentasi. Teknik analisis data yang dilakukan melalui pengumpulan data, reduksi data, tampilan data, serta simpulan. Indikator penelitian dapat diklasifikasikan melalui identitas sosial, kohesi sosial, mekanisme kontrol, sumber motivasi, dan sumber inspirasi dari nilai budaya lokal (sipakatau). Sipakatau dalam bahasa Bugis berarti rasa saling menghargai satu sama lain. Penelitian ini menunjukkan bahwa nilai budaya lokal (sipakatau) telah berfungsi sebagai identitas sosial, sosial kohesi, mekanisme kontrol, sumber motivasi, dan sumber inspirasi di Rumah Sakit Wahidin Sudirohusodo Makassar.
\end{abstract}

Kata kunci: sipakatau, nilai lokal, organisasi publik, menghargai orang lain, identitas sosial

\section{Pendahuluan}

Organisasi menurut Torang (2013) adalah sistem peran, aliran aktivitas dan proses atau pola hubungan kerja sama yang melibatkan beberapa orang yang didesain untuk mencapai tujuan bersama. Organisasi dapat dibedakan dalam dua jenis, yaitu organisasi non pemerintah (swasta/ perusahaan) dan organisasi publik (pemerintah). 
Organisasi publik mendominasi hampir seluruh aspek kehidupan masyarakat. Fakta empiris menunjukkan bahwa organisasi publik masih memiliki tiga fungsi, yaitu fungsi; manajemen, distribusi, dan pelayanan publik.

Organisasi publik adalah instrumen pemerintah yang difungsikan dalam memberikan pelayanan kepada masyarakat. Demikian pula Syafiie et al. (1999) menjelaskan bahwa organisasi publik dilihat dalam bentuk organisasi adalah instansi pemerintah yang juga dikenal dengan istilah birokrasi. Di samping itu, organisasi publik juga difungsikan untuk mengarahkan, menfasilitasi, membimbing serta menciptakan suasana yang menunjang kegiatan-kegiatan masyarakat. Organisasi publik harus memiliki dan mengimplementasikan budaya organisasinya dengan optimal.

Setiap organisasi publik memiliki ciri (characteristic) nilai budaya organisasi yang difungsikan untuk membedakannya dengan organisasi publik lainnya. Untuk mendekatkan organisasi publik dengan lingkungan sosialnya (masyarakat), maka organisasi publik sebaiknya memedomani nilai-nilai budaya lokal, dengan demikian, semua sistem peran, aliran aktivitas dan pola hubungan kerja sama (proses) dalam organisasi publik, tentu diwarnai oleh ciri nilai budaya organisasi yang dipedomani.

Budaya yang dipedomani oleh setiap sumberdaya manusia organisasi disebut sebagai budaya organisasi (organization culture). Menurut Schein (1997), budaya organisasi dapat dianalisis dalam 3 (tiga) tingkatan yang berbeda, yaitu: artifacts, espoused values, dan basic underlying assumptions. Schein menambahkan bahwa nilai (espoused values) yang dianut/ dipedomani oleh setiap organisasi, akan menjadi asumsi dasar bersama dalam mengatasi problema adaptasi internal (problems of external adaptation) dan integrasi internal (internal integration).

Robbins (2002) berpendapat bahwa budaya organisasi adalah suatu persepsi bersama yang dianut oleh anggota-anggota organisasi; sistem makna bersama yang dipedomani oleh setiap orang di dalam organisasi. Selanjutnya Robbins menjelaskan bahwa sistem makna, merupakan karakteristik nilai budaya organisasi yang disebut sebagai espoused value.

Amstrong (1998) menegaskan bahwa budaya organisasi adalah pola nilai, norma, keyakinan, sikap dan asumsi yang dapat diartikulasikan. Menurut Kreitner \& Kinicki (2001) budaya organisasi adalah nilai dan keyakinan bersama yang mendasari identitas organisasi. Wibowo (2010) juga menegaskan bahwa budaya organisasi menunjukkan nilai (value), keyakinan (beliefs), prinsip, tradisi, dan cara sekelompok orang beraktifitas dalam organisasi.

Selanjutnya Chatab (2007) menetapkan bahwa ada 5 (lima) manfaat nilai (espoused value) organisasi, yaitu: 1) sebagai pedoman berperilaku dalam mewujudkan misi organisasi; 2) sebagai sumber 'power' dan 'motivasi' dalam bertindak dan dipegang teguh oleh setiap individu dalam organisasi; 3) merefleksikan dan memperkuat budaya organisasi; 4) mengarahkan pengambilan keputusan dalam organisasi; dan 5) memudahkan pencapaian visi dan menjalankan misi.

Robbins (2002) dan Chatab (2007) menggambarkan bahwa budaya organisasi pada organisasi publik dapat difungsikan sebagai identitas sosial (social identity), stabilitas sosial (social stability), pedoman (guidance), serta pembentuk pola sikap dan perilaku sumber daya manusia. Budaya organisasi juga dapat difungsikan sebagai pemersatu (social cohesion), sumber inspirasi, sumber penggerak (motivasi), peningkatan nilai tambah, pengganti formalisasi, dan mekanisme adaptasi terhadap perubahan.

Sebagai rumah sakit milik pemerintah (organisasi publik), Rumah Sakit Umum Pusat Wahidin Sudirohusodo Makassar (RSWS) telah memiliki nilai-nilai budaya organisasi sebagai ciri (characteristic) budaya organisasinya yang dianut/dipedomani oleh semua sumber daya manusianya dalam memberikan pelayanan medis. Nilai-nilai tersebut adalah inovatif, professional, empati, kerja sama, dan salah satu di antaranya adalah nilai budaya lokal yang diadopsi dari nilai budaya BugisMakassar, yaitu; sipakatau. 


\section{Metode Penelitian}

Jenis penelitian ini adalah kualititatif dengan menggunakan pendekatan studi kasus. Spradley (1980) berpendapat bahwa penelitian kualitatif diaplikasikan dengan cara mengamati dan menganalisis situasi sosial (social situation). Situasi sosial yang dimaksudkan oleh Spradley adalah tempat (place), pelaku (actor), dan aktifitas (activity) yang berinteraksi secara sinergi.

Creswell (1994) mengungkapkan bahwa studi kasus merupakan salah satu bagian dari penelitian kualitatif yang diaplikasikan dengan cara mengeksplorasi secara mendalam terhadap program, kejadian/ tempat, proses, aktivitas beberapa orang atau kelompok. Eksplorasi dimaksudkan untuk menjaga keutuhan dan integrasi semua objek yang diteliti.

Informan penelitian adalah tenaga medis dan non medis rumah sakit (internal) serta pasien dan keluarganya (eksternal). Informan diperoleh melalui teknik 'purposive sampling'.

Data diperoleh dengan menggunakan teknik wawancara terstruktur (strtuctured interview), observasi partisipasi pasif dan telaah dokumen. Teknik analisis data penelitian dilakukan dalam 4 (empat) tahapan, yaitu: 1) pengumpulan data, 2) reduksi data (data reduction), 3) penyajian data (display data), dan 4) simpulan (conclusion).

Fokus penelitian ini adalah fungsi-fungsi nilai budaya lokal "sipakatau" pada organisasi publik (Rumah Sakit Wahidin Sudirohusodo Makassar). Dimensi fungsi-fungsi nilai budaya lokal yang diamati dan dianalisis, yaitu fungsi sebagai: identitas sosial, perekat sosial, pembentuk pola sikap, sumber motivasi, dan sumber inspirasi.

\section{Hasil Penelitian dan Pembahasan}

Sebagai organisasi publik, Rumah Sakit Umum Pusat Wahidin Sudirohusodo Makassar (RSWS) adalah rumah sakit yang berada di tengah-tengah mayoritas masyarakat Bugis dan Makassar. Oleh karena itu, mayoritas pasien rumah sakit tersebut adalah masyarakat Bugis dan Makassar. Pasien rumah sakit tidak hanya berasal dari Kota Makassar, melainkan juga berasal dari berbagai kota dan kabupaten di Sulawesi Selatan dan dari berbagai propinsi di wilayah Indonesia Timur.

RSWS adalah Unit Pelaksana Teknis (UPT) Departemen Kesehatan RI dengan Pola Pengelolaan Keuangan Badan Layanan Umum. Pada tahun 2014, RSWS ditetapkan sebagai Rumah Sakit yang berstandar Internasional setelah memperoleh Akreditasi KARS Paripurna dan Akreditasi JCI. Pada tanggal 17 Oktober 2014, melalui surat keputusan Menteri Kesehatan; No. HK. 02. 02/ MenKes/ 390/ 2014 RSWS ditetapkan sebagai rumah sakit rujukan nasional.

Seperti yang telah penulis jelaskan bahwa sebagai organisasi publik, RSWS juga telah memiliki budaya organisasi dan salah satu di antaranya adalah nilai "sipakatau" yang diadopsi dari nilai lokal budaya Bugis - Makassar. Nilai tersebut dipedomani dalam memberikan pelayanan publik. Sipakatau dalam Bahasa Indonesia artinya adalah sikap saling menghormati dan atau saling menghargai antar sesama umat manusia tanpa memandang status sosialnya.

Salah satu tugas utama organisasi menurut Esman dan Uphoff (1984) adalah menjembatani masyarakat lokal dengan pemerintah. Pendapat Esman dan Uphoff ini disadari oleh RSWS sehingga mengadopsi nilai sipakatau agar dapat menjembatani rumah sakit tersebut dengan masyarakat lokal yang membutuhkan pelayanan medis.

Oleh karena itu, salah satu dimensi lingkungan organisasi yang harus mendapatkan perhatian adalah lingkungan sosial atau kondisi sosial dan budaya, termasuk nilai-nilai yang berlaku di masyarakat, norma-norma, tradisi dan sikap-sikap. 
Untuk menuju taraf menjadi organisasi publik yang efektif, maka RSWS menempatkan nilai budaya lokal, yaitu nilai sipakatau sebagai nilai inti yang dipedomani secara intrinsik agar mendapatkan dukungan masyarakat sebagai lingkungan eksternalnya. Oleh karena itu, nilai sipakatau juga dipedomani oleh tenaga medis dan non medis RSWS sebagai nilai inti dalam bekerja. Menurut Nasucha (2004), nilai-nilai inti yang dipegang teguh dan telah disepakati bersama oleh anggota organisasi akan menjadi budaya yang kuat. Banyaknya anggota yang memegang teguh nilai-nilai inti tersebut mencerminkan komitmen yang kuat terhadap nilai inti tersebut.

Nilai sipakatau yang dipedomani sebagai nilai inti secara intrinsik oleh semua sumberdaya RSUP Wahidin Sudirohusodo Makassar (RSWS), difungsikan sebagai; Identitas sosial (social identity), Dengan nilai sipakatau, manajemen RSWS memberi pesan kepada masyarakat Indonesia bahwa rumah sakit ini adalah organisasi publik yang masih mengedepankan nilai kearifan lokal atau nilai budaya lokal Bugis-Makassar. Di samping itu, rumah sakit juga memberi pesan bahwa dalam memberikan pelayanan medis kepada masyarakat, setiap tenaga medis dan non medis mengutamakan sikap saling menghargai dan saling menghomati kepada siapapun.

Oleh karena itu, nilai sipakatau adalah identitas RSWS yang dipedomani secara instrinsik sebagai nilai inti untuk mencapai tujuannya. Hal ini sejalan dengan pendapat Budiharjo (2011) yang menggambarkan bahwa nilai-nilai inti organisasi (budaya organisasi) merupakan identitas organisasi yang diinginkan oleh pemilik organisasi yang dipersepsikan sebagai suatu entitas yang memiliki karakter atau nilai khas yang ditananamkan pada semua orang yang bekerja pada organisasi tersebut agar mereka menghayati nilai-nilai yang dikehendaki untuk mengarahkan perilaku anggota/ pekerjannya.

Perekat sosial (social cohesion), karena nilai "sipakatau" menuntut setiap tenaga medis dan non medis harus saling mengormati/ menghargai dalam melaksanakan tugasnya, maka mereka mengaplikasikan nilai sipakatau sebagai social cohesion dalam konsep human relation. Konsep ini sejalan dengan pendapat Terry (1958) yang menegaskan bahwa;

...by human relations is meant the integration of the manpower resource for effective and maximum utilization by means of satisfying human wants and the maintaining of satisfactory relationships among the member is seeking these human wants...

Agar tetap terjaga fungsi social cohesion dalam nilai sipakatau, maka ada beberapa cara pimpinan RSWS dalam mengaplikasikan konsep human relation, yaitu; 1) mengakui perbedaan-perbedaan setiap tenaga medis dan non medis, karena mereka menyadari bahwa setiap orang memiliki perbedaan. Baik perbedaan etnis, agama, maupun perbadaan pandangan dan pikiran/ pendapat. Oleh karena itu, dalam berbagai kesempatan atau rapat, mereka saling memberikan peluang dalam menyampaikan pendapatnya tanpa menginterupsinya. 2) menghindari perdebatan (arguments) karena mereka beranggapan bahwa perdebatan tidak menyelesaikan perbedaan. Terry menegaskan; "the winner of an argument is nebulous concept; nothing is won, and actually a great deal is lost". 3) saling memahami perasaan (deep feeling) karena mereka memahami bahwa setiap manusia biasanya sentimental terkait dengan 'personal attachment, experiences, dan emotions' yang bertentangan dengan pengalaman pribadinya. Perasaan yang mendalam tersebut mereka manfaatkan untuk membangun hubungan yang baik. 4) menggunakan pertanyaan-pertanyaan yang dapat memengaruhi orang, karena mereka mengetahui bahwa bertanya pada seseorang, memberi peluang pada yang bersangkutan untuk menginformasikan apa yang dia tahu dan untuk memberi kesan kepada orang lain tentang pengetahuan yang dia miliki, dan 5) menghindari sikap yang mendominasi, karena mereka sudah bersepakat untuk saling menghargai dan menghormati. Mereka menyadari bahwa setiap orang akan melakukan pekerjaan atau mereka akan membantu orang lain apabila mereka merasa senang (tidak didominasi).

Pembentuk pola sikap (sense-making and control mechanism), nilai sipakatau yang telah menjadi asumsi dasar bersama sumber daya manusia RSWS, juga berfungsi sebagai pembentuk pola sikap agresif (tidak santai) dan kompetitif sumber daya manusia RSWS dalam melaksakan tugasnya. Salah 
satu strategi pimpinan rumah sakit dalam menjaga pola sikap agresif para tenaga medis dan non medisnya dalam bekerja, adalah: 1) mengetahui kesesuaian kompetensi yang dimiliki oleh seseorang dengan tugas yang diberikan padanya (the right man on the right place), 2) mengetahui kesesuaian waktu dengan hasil pekerjaan. 3) melaksanakan pengawasan dan apabila ditemukan kesalahan atau kekeliruan, segera dilakukan perbaikan sehingga tujuan organisasi dapat tercapai dengan efektif dan efisien, 4) menjamin agar semua pekerjaan yang sedang dilakukan bejalan sesuai dengan rencana yang telah ditentukan sebelumnya, 5) mengukur hasil kinerja, 6) mempelajari perkembangan pekerjaan secara berkesinambungan dengan memonitor pekerjaan yang sedang berlangsung, 7) melakukan usaha-usaha untuk mengurangi, menghindari atau malah menyelesaikan faktor-faktor yang menghambat pekerjaan, 8) menyediakan reward bagi tenaga medis dan non medis yang berprestasi.

Salah satu wujud dari pola sikap sumberdaya manusia RSWS yang telah terbentuk adalah bekerja dengan mengutamakan proses (process oriented) untuk mendapatkan hasil (outcome oriented). Dalam memberikan pelayanan, semua aktifitas kerja mereka harus mengacu pada standar operational procedures (SOP) dan dokumen care of patients (COP).

Nilai sipakatau juga difungsikan sebagai sumber motivasi. Oleh karena itu, agar fungsi ini berjalan optimal, maka setiap pimpinan team work pada RSWS melakukan beberapa kebijakan sebagai berikut: 1) memposisikan setiap tenaga medis dan non medis sebagai sumberdaya manusia yang dibutuhkan, 2) menganggap penting dan berarti keberadaan setiap tenaga medis dan non medis. Pengakuan terhadap keberadaan dan status mereka merupakan pertimbangan yang paling utama, 3) menyadari bahwa keinginan seseorang untuk diterima oleh pihak lain merupakan hal yang sangat penting sehingga setiap orang bersikap loyal, termotivasi dan dengan ikhlas melaksanakan dan menyelesaikan tugas pokok dan fungsinya, 4) meminta pendapat dan saran setiap tenaga medis dan non agar merasa dihargai apabila diminta pendapat dan sarannya.

Apa yang telah dilakukan oleh setiap pimpinan team work pada RSWS merupakan aplikasi dari pendapat Maslow (1984), bahwa setiap orang akan termotivasi dalam bekerja apabila terpenuhi kebutuhan sosialnya (social needs) dan kebutuhan penghargaan (esteem needs). Salah satu wujud fungsi ini adalah meningkatkan motivasi kerja sumber daya manusianya yang diimplementasikan dalam konsep tim kerja (team work). Pembentukan team work dimaksudkan agar semua bentuk kegiatan atau pekerjaan harus diwujudkan bersama dalam tim kerja (team work) organisasi.

RSUP Wahidin Sudirohudo Makassar memiliki empat team work dalam memberikan pelayanan medis pada masyarakat, yaitu; 1) tim kerja pimpinan (top leader team work), 2) tim kerja teknis (skill team work), 3) tim kerja pengawas (non structural), dan 4) tim kerja divisi rawat inap. Setiap tim kerja melakukan rapat koordinasi internal dan eksternal sebelum dan sesudah melakukan kegiatan. Rapat koordinasi internal dilakukan antar sesama anggota kelompok tim masing-masing. Rapat koordinasi eksternal dilakukan oleh masing-masing pimpinan tim kerja. Rapat koordinasi merupakan wujud saling menghormati dan saling menghargai antar sesama tim kerja atau saling menghargai kewenangan masing-masing tim kerja.

Tujuan rapat koordinasi tersebut sejalan dengan pendapat Terry (1958) yang menegaskan bahwa:

Coordination is the orderly synchronization of efforts to provide the proper amount, timing, and directing of execution resulting in harmonious and unified actions to a stated objective and coordinating helps maximize the achiement of a group by means of obtaining a balance among, and a smooth blending of, the essential component activities, encouraging the group's participation in the early stages of planning, and winning acceptance of the group's goal from every members.

Di dalam tim kerja divisi rawat inap, ada juga tim kerja perawatan medis. Tim kerja ini bekerja pada setiap ruangan rawat inap dan bertanggung jawab atas semua pelayanan yang diberikan kepada pasien yang rawat inap. Tim kerja yang bertugas dalam ruang rawat inap tersebut terdiri dari 6 (enam) orang, 
yaitu: 1) ketua tim, 2) dokter penanggung jawab, 3) kepala pelayanan, 4) dokter kerja sama, 5) perawat pelaksana, dan 6) dietisien.

Tugas tim kerja tersebut adalah: 1) mengidentifikasi pasien secara benar, 2) berkomunikasi dengan pasien secara efektif, 3) menjaga keamanan pemberian obat, 4) mengurangi resiko infeksi (dengan mencuci tangan dengan benar), 5) bertindak dengan tepat lokasi, tepat prosedur, tepat pasien operasi, dan 6) mengurangi resiko jatuh.

Ketua tim kerja bertugas untuk mengkoordinasikan kegiatan medis pada ruang rawat inap. Dalam melaksanakan tugasnya, ketua tim dibantu oleh perawat pelaksana dan dietisien. Perawat pelaksana betugas untuk membantu dokter, misalnya memeriksa tekanan darah pasien dan menyimpan rekam medis pasien. Dokter penanggung jawab bertugas atas diagnosa (pemeriksaan rutin) dan pengobatan pada pasien dan dokter penanggung jawab dibantu oleh satu orang dokter kerja sama. Kepala pelayanan adalah pimpinan ruang rawat inap yang bertanggung jawab atas semua pelayanan yang dibutuhkan oleh pasien, mulai dari kebutuhan obat sampai pada kebutuhan konsumsi.

Sumber inspirasi, nilai sipakatau yang telah menjadi asumsi dasar bersama (basic underlying assumption), menjadi sumber inspirasi pimpinan RSWS untuk berinovasi. Salah satu bentuk inovasi pimpinan RSWS adalah penyediaan tempat singgah/tempat penginapan/tempat istirahat bagi keluarga pasien yang tidak memiliki keluarga di Kota Makassar.

Pimpinan RSWS menyadari bahwa salah satu aktifitas sosial yang masih selalu dilakukan oleh masyarakat perdesaan khususnya adalah mengunjungi pasien (keluarga yang sakit) dengan berkelompok. Apabila ada seorang keluarganya yang dirawat di rumah sakit, maka semua keluarganya akan datang menjenguk/mengunjungi.

Kondisi sosial inilah yang menginspirasi pimpinan RSWS untuk membangun tempat singgah/ tempat penginapan/tempat istirahat bagi keluarga pasien sebagai bentuk inovasi. Inovasi dalam organisasi menurut Greenberg dan Baron (1997) adalah suatu usaha yang dilakukan oleh sumberdaya organisasi dalam melakukan kreatifitas dan menemukan gagasan baru dalam bekerja. Tempat tersebut juga difungsikan sebagai tempat silaturahmi bagi keluarga yang lama tidak bertemu.

\section{Simpulan}

Nilai sipakatau telah difungsikan oleh Rumah Sakit Umum Pusat Wahidin Sudiro Husodo (RSWS) sebagai identitas sosial (social identity), perekat sosial (social cohesion), pembentuk pola sikap (sense-making and control mechanism), sumber motivasi (motivation source), dan sumber inspirasi (inspiration source).

Nilai sipakatau telah menjadi ciri nilai budaya organisasi (characteristic value) RSWS. Nilai sipakatau dipedomani sebagai nilai inti RSWS dan dipedomani secara intrinsik. Oleh karena itu, nilai sipakatau telah menjadi asumsi dasar bersama bagi semua tenaga medis dan non medis rumah sakit tersebut.

Impilikasi Teoritis: Nilai-nilai budaya lokal dapat menjadi sumber teori budaya organisasi publik. Nilai-nilai budaya lokal tidak hanya dapat dipedomani dalam kehidupan informal, tetapi juga dapat dipedomani dalam kehidupan formal, khususnya dalam organisasi publik.

Implikasi Praktis: Untuk lebih mengoptimalkan pelayanan pada organisasi publik, khususnya rumah sakit pemerintah, maka sebaiknya setiap organisasi publik memerhatikan lingkungan sosialnya atau kondisi sosial dan budaya masyarakatnya, dengan memedomani nilai-nilai budaya lokal sebagai asumsi dasar bersama dalam memberikan pelayanan publik. 


\section{Daftar Pustaka}

Amstrong M and Baron A (1998) Performance Management. London: Institute of Personnel and Development.

Budiharjo A (2011) Organisasi: Menuju Pencapaian Kinerja Optimum. Jakarta Selatan: Prasetiya Mulya Publishing.

Chatab N (2007) Profil Budaya Organisasi. Bandung: Penerbit Alfabeta.

Creswell JW (1994) Research Design: Qualitative \& Quantitative approaches. USA: Sage Publication.

Esman MJ dan Uphoff N (1984) Local Organization Intermediares in Rural Development. Ithaca: Cornell University Press.

Greenberg J and Baron RA (1997) Behavior in Organization. New Jersey: Prentice-Hall International, Inc.

Kreitner R and Kinicki A (2001) Organizational Behavior. New York: McGraw-Hill Higher Education.

Maslow A (1984) Motivasi dan Kepribadian. (Terjemahan) Jakarta: Pustaka Binaman Pressindo.

Nasucha C (2004) Reformasi Administrasi Publik: Teori dan Paraktek. Jakarta: Grasindo.

Robbins SP (2002) Perilaku Organisasi. Jakarta: Prenhallindo.

Syafiie IK, Tandjung D, Modeong S (1999) Ilmu Administrasi Publik. Jakarta: Rinela Cipta.

Schein EH (1997) Organizational Culture and Leadership. San Francisco: Jossey-Bass Publisher.

Spreadley J (1980) Participant Observation. New York: Holt, Rinehart and Winston.

Terry GR (1958) Principles of Management. United State of America: Richard D. Irwin Inc.

Torang S (2013) Organisasi dan Manajemen. Bandung: Alfa Beta Bandung.

Wibowo (2010) Budaya Organisasi: Sebuah Kebutuhan untuk Meningkatkan Kinerja Jangka Panjang. Jakarta: PT. Rajawali Pers. 